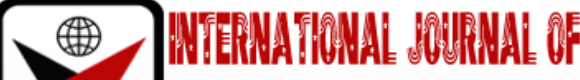

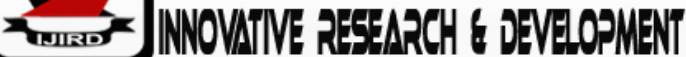

ISSN 2278-0211 (Online)

\section{Impact of Bank Loan on Artisanal Fishing in Rivers State: A Case of Bank of Agriculture (BOA)}

\author{
Iroegbu Innocent \\ Lecturer, Captain Elechi Amadi Polytechnic Port Harcourt Rivers State, Nigeria \\ Okidim I. A. \\ Lecturer, Department of Agriculture and Applied Economics, \\ Rivers State University Port Harcourt, Nigeria \\ Ekine D. l. \\ Lecturer, Department of Agriculture and Applied Economics, \\ Rivers State University Port Harcourt, Nigeria
}

\begin{abstract}
:
The study focused on the impact of Bank loan on Artisanal Fishing in Rivers State: A case of Bank of Agriculture (BOA). The objectives of the study were to identify the Socio-economic characteristics of the fishers. Identify areas of impact from the Bank Loan and possible challenges. Purposive and random sampling were adopted to select (60) BOA loan beneficiaries and 40 non beneficiaries. Descriptive and inferential statistical tools were used in analysis such as frequencies and Likert-scale, etc. Socio-economic characteristics of the respondents shows that average age of loan beneficiaries was 47.3, non-beneficiaries was 42.9, About 86.6\% of beneficiaries and 70\% non-beneficiaries were male, 13.33 and 30\% respectively, were female. Average family size was 5.6 and 5 for both beneficiaries and nonbeneficiaries. About $66.67 \%$ and $77.5 \%$ of beneficiaries and non-beneficiaries has at least secondary school education. The result showed that, there was significant improvement in the income of the beneficiaries of BOA Loan, most of them invested the loan to expand their operations, purchase fishing gears which resulted in increased output/catch. Some of the challenges include: Distance to the city, documentation process and mandatory cash deposit as well as volume and timing of the loan, insecurity of water ways, Obnoxious activities of oil companies/ pollution of water and lack of equipment etc. The study recommended that more attention should be focused on granting of loans to rural and artisanal fisher folks, the Bank should open rural branches and cash offices. Government and Non-Governmental agencies should be encouraged to make fund available, adequate policing of the water ways to check the activities of sea pirates. Multinational oil companies should adopt international best practices to minimize pollution of our water and marine environment.
\end{abstract}

Keywords: Impact, bank loan, artisanal fishing, bank of agriculture

\section{Introduction}

Traditionally, capital for investment in agriculture comes from two potential sources, normally personal savings of the farmer and farm credit from financial institutions. However, because of low yield and price uncertainty associated with fishing and farming in developing economies, farmers are often entangled in the vicious cycle of low output-low income-low savings and low investment which again results to low output, this is often referred to as the vicious cycle of poverty (Nwankwo, 2005) therefore, farm credit either from the formal or informal source remains the major means of improving fishing and farming in the country. Consequently upon this, Nigerian government has intervened several times to inject farm credit into the agricultural subsector of the economy. The first attempt at institutional credit for agriculture in Nigeria was made in 1947 with the establishment of the farmers and commercial bank (Adegeye, 1982).

Although the farmers and commercial bank collapsed in 1953, the Nigerian Agricultural Bank (NAB) was established and incorporated in 1973 as Nigerian Agricultural and Co-operative Bank (NACB) and therefore became the apex agricultural financial institutions in Nigeria. However, the need to give special attention to various groups of fishermen and farmers, as well as small-scale artisans who contributed to the overall economy of the nation gave birth to the establishment of Nigerian Agricultural Co-operative and Rural Development Bank (NACRDB) through a merger of the former (PBN) people's Bank of Nigeria, the Nigerian Agricultural and Co-operative Bank (NACB) limited and the Risk assets of defunct Family Economic Advancement Programme (FEAP) in October 2000.

Empirical studies showed that lack of access to adequate credit can have significant negative consequences on agricultural productivity, technology adoption, food security and overall welfare of farmers and fishermen (Diagne and Zelber, 2001). Farm credit has long been identified as a major input in the development of the fisheries sector in Nigeria. It is very interesting to note that very little foreign capital, private or international has ever gone into the traditional fishing 
and farming. The meagre amount of resources invested in the traditional fishing and farming enterprises by the international development agencies like World Bank have been criticize (Shonfield, 1960). In the absence of foreign investment, the source of capital for the expansion of the fishing and farming in our rural communities remains relatively limited.

Nigeria, with her huge petroleum export base, had over the years neglected the commensurate funding of the agricultural sector, the resulting effects are the problems of food shortage, excess vices among the youths due to unemployment, militancy, kidnapping, banditry, fraud. Rubbery, assassination, prostitution, oil theft (Bunkery). Even though farm credit (Loans) has long been identified as a major input in the development of the fishery sector in Nigeria, however, the involvement of Government and financial institution in funding the fishery sector is restively insufficient. In the opinion of Abdulaziz (2007) for Nigeria to achieve her vision 2020, there must be a mechanization to give resources and loans in the economic development process.

To tackle this scourge, the Federal Government of Nigeria in the year 2005, under the leadership of Chief Olusegun Obasanjo instructed that sum of N50 billion be domiciled with NACRDB limited to lend to farmers and fishermen at concessionary interest rate. It is therefore our objective to examine the impact of the Nigerian Agricultural co-operative and Rural Development Bank (NACRDB), currently Bank of Agriculture (BOA) loan on the productivity output and profit level as well as socio-economic wellbeing of the beneficiaries and non-beneficiary artisanal fish farmers in Rivers state.

\section{Methodology}

\subsection{Study Area}

This study was carried out in Rivers State. The state is bounded on the South by the Atlantic Ocean, to the east by Imo, Abia, Akwa/Ibom States and to the West by Bayelsa and Delta States. Rivers State is situated at the Niger Delta with a typical tropical rainforest environmental feature. It is generally regarded as the treasure base of the nation due to her rich natural resources, with a landmass area of $11,077 \mathrm{~km}^{2}$ located $4{ }^{\circ} 45^{\mathrm{N}}, 6050^{\mathrm{E}}$. The study covered mainly the riverine communities engaged in artisanal fishing activities as they are well known for fishing.

\subsection{Source of Data and Method of Collection}

For the purpose of accurate information, a well-structured questionnaire was administered purposively to sixty (60) NACRDB loan beneficiaries who benefited from the Bank Loan between 2005 and 2010, who were also registered fishermen with the State Ministry of Agriculture, under the umbrella body of 'AFAAN' all farmers Apex Association of Nigeria. The other 40 fishermen were randomly selected from among the eight riverine communities, five from each of the community.

Additional secondary data were obtained from records provided by NACRDB, the Farmers Association and Rivers State Ministry of Agriculture; also some fishermen were interviewed to get more facts.

\section{Results and Discussion}

\begin{tabular}{|c|c|c|c|c|c|c|c|}
\hline \multicolumn{4}{|c|}{ Loan Beneficiaries } & \multicolumn{4}{|c|}{ Non-Beneficiaries } \\
\hline & Frequency & $\%$ & Mean & Frequency & $\%$ & Mean & \\
\hline \multicolumn{8}{|l|}{ Age } \\
\hline $15-25$ & 0 & 0 & & 2 & 5 & & \\
\hline $26-35$ & 4 & 6.67 & & 6 & 15 & & \\
\hline $36-45$ & 18 & 30 & & 16 & 40 & & \\
\hline $46-55$ & 33 & 55 & & 12 & 30 & & \\
\hline $56-65$ & 5 & 8.33 & & 4 & 10 & & \\
\hline Total & 60 & 100 & 47.3 & 40 & 100 & 42.9 & \\
\hline \multicolumn{8}{|l|}{ Gender } \\
\hline Male & 52 & 86.67 & & 28 & 70 & & \\
\hline Female & 8 & 13.33 & & 12 & 30 & & \\
\hline Total & 60 & 100 & & 40 & 100 & & \\
\hline \multicolumn{8}{|c|}{ Marital Status } \\
\hline Married & 51 & 85 & & 25 & 62.5 & & \\
\hline Single & 4 & 6.67 & & 10 & 25 & & \\
\hline Divorced & - & - & & - & - & & \\
\hline Widowed & 5 & 8.33 & & 5 & 12.5 & & \\
\hline Total & 60 & 100 & & 40 & 100 & & \\
\hline \multicolumn{8}{|c|}{ Household Size } \\
\hline 01-Mar & 10 & 16.67 & & 8 & 20 & & \\
\hline 04-Jun & 32 & 53.33 & & 5 & 12.5 & & \\
\hline 07-Sep & 14 & 23.33 & & 6 & 15 & & \\
\hline 10-Above & 4 & 6.67 & & 1 & 2.5 & & \\
\hline Total & 60 & 100 & 5.6 & 40 & 100 & 5 & \\
\hline
\end{tabular}




\begin{tabular}{|c|c|c|c|c|c|c|c|c|}
\hline \multicolumn{4}{|c|}{ Loan Beneficiaries } & \multicolumn{5}{|c|}{ Non-Beneficiaries } \\
\hline & Frequency & $\%$ & Mean & & Frequency & $\%$ & Mean & \\
\hline Educational Background & & & & & & & & \\
\hline Formal Education & 60 & 100 & & & 40 & 100 & & \\
\hline Informal Education & - & 0 & & & 0 & 0 & & \\
\hline Adult Education & - & 0 & & & - & - & & \\
\hline Primary Education & 18 & 30 & & & 5 & 12.5 & & \\
\hline Secondary Education & 40 & 66.67 & & & 31 & 77.5 & & \\
\hline Tertiary Education & 2 & 3.33 & & & 40 & 10 & & \\
\hline Total & 60 & 100 & & & 40 & 100 & & \\
\hline Major Occupation & & & & & & & & \\
\hline Fishing & 58 & 96.69 & & & 35 & 87.5 & & \\
\hline Farming & 0 & 0 & & & 0 & - & & \\
\hline Civil Servant & 2 & 3.33 & & & 5 & 12.5 & & \\
\hline Any other & 0 & 0 & & & 0 & - & & \\
\hline Total & 60 & 100 & & & 40 & 100 & & \\
\hline Year of Experience in fishing & & & & & & & & \\
\hline 01-May & 0 & 0 & & & 1 & 2.5 & & \\
\hline $06-0 \mathrm{ct}$ & 2 & 3.33 & & & 2 & 5 & & \\
\hline Nov-15 & 8 & 13.34 & & & 20 & 50 & & \\
\hline $16-20$ & 30 & 50 & & & 12 & 30 & & \\
\hline 21-Above & 20 & 33.33 & & & 5 & 12.5 & & \\
\hline Total & 60 & 100 & 18.67 & 3.93 & 40 & 100 & 15.25 & 5.12 \\
\hline $\begin{array}{c}\text { Membership of Cooperative } \\
\text { Society }\end{array}$ & & & & & & & & \\
\hline Yes & 50 & 83.33 & & & 25 & 62.5 & & \\
\hline No & 10 & 16.67 & & & 15 & 37.5 & & \\
\hline Total & 60 & 100 & & & 40 & 100 & & \\
\hline Sources of Capital/Funding & & & & & & & & \\
\hline Personal Savings & 0 & 0 & & & 20 & 50 & & \\
\hline Friends \& Relations & 0 & 0 & & & 8 & 20 & & \\
\hline Money Lenders & 0 & 0 & & & 2 & 5 & & \\
\hline Commercial Banks & 0 & 0 & & & 0 & 0 & & \\
\hline Agric. Bank & 60 & 100 & & & 0 & 0 & & \\
\hline Co-operative Contribution & 0 & 0 & & & 10 & 25 & & \\
\hline Total & 60 & 100 & & & 40 & 100 & & \\
\hline Religion of Respondents & & & & & & & & \\
\hline Christianity & 42 & 70 & & & 28 & 70 & & \\
\hline Islam & 2 & 3.33 & & & 4 & 10 & & \\
\hline Traditional Religion & 16 & 26.67 & & & 8 & 20 & & \\
\hline Total & 60 & 100 & & & 40 & 100 & & \\
\hline
\end{tabular}

Table 1: Shows Socio-economic Characteristics of Respondents

Source: Field Survey, 2019

Table 1 is showing a Summary of Socio-Economic Characteristics of Respondents

\subsection{Socio-Economic Characteristic of Respondents}

\subsubsection{Age}

From Table 1 showed that none of the loan Beneficiaries fell between the ages $15-25$, while only about $5 \%$ of the non-beneficiaries were of that range.

$6.67 \%$ of the loan beneficiaries were of ages $36-35,15 \%$ of the non-beneficiaries were of within this age range, $30 \%$ of the loan beneficiaries were within the age range of 36-45 years, on the other hand $40 \%$ non-beneficiaries were of age range. However, $55 \%$ of the loan beneficiaries were of age 46-55 years as against $30 \%$ of non-beneficiaries, about $8.5 \%$ of loan beneficiaries were of the age range of 56-65, whereas 10 of non-beneficiaries were in that age range.

From the above results it could be seen that $55 \%$ of the Loan Beneficiaries were of the age 46-55 years which indicates that these people have gotten sufficient and reasonable experiences in artisanal fishing, closely followed by $30 \%$ who are of the age range of 36-45 also matured and experienced in artisanal fishing practices.

On the other hand, $40 \%$ of non-beneficiaries also fell under the range of $36-45,30 \%$ were between $46-55$ years. Generally, the results here shows that majority of the respondent were between the age 36-55years, which means that they were still within the productive age. 
This is in line with the study of Olomola (1988), and Bello (2000) who both maintained that age has a positive correlation to fishing and farming.

\subsubsection{Gender}

Table 1 shows that from both beneficiaries and non-beneficiaries' greater percentage of artisanal fishers (respondents) were male. For loan beneficiaries $86.6 \%$ were male, $13.3 \%$ female, and for non-beneficiaries $70 \%$ were male $30 \%$ female. This result is contrary to some authors who tend to perceive artisanal fishing as occupation for the female folks. It is in disagreement with Lahia et al. (2000) which seem to suggest that women participate more than men in fishing and farming. However, it seems to align with the finding of Babalola (2014).

This result does not however suggest that artisanal fishing is limited to a particular sex or gender as both male and female folks can conveniently and fully be engaged in artisanal fishing.

\subsubsection{Marital Status}

Table 1 Shows that greater percentage of both loan beneficiaries and non-beneficiaries were married. For loan beneficiaries $85 \%$ married, $8.3 \%$ widowed $6.6 \%$, single, but for non-beneficiaries $62.5 \%$ were married, $25 \%$ single, $12.5 \%$ widowed, from this result it is possible to agree that these families engaged in fishing as means of livelihood.

This is also supported by the findings of Okunola (2014) who indicated that most families engaged in fishing and farming as their main source of income. This implies that more of the loans were given to married respondents, it further implies that the effect of loan will spread better and faster.

\subsubsection{Household Size}

Table 1Shows that, for both loan Beneficiaries and non-beneficiaries a greater percentage of the respondents have house hold size of between 4-6 persons, Aggregate of about $53.3 \%$ of beneficiaries and $52.5 \%$ of non-beneficiaries. Also $23.3 \%$ and $15 \%$ non-beneficiaries have family size of $7-9$, persons $16.67 \%$ of beneficiary and $20 \%$ of non-beneficiaries have family size of $1-3$, while $6.67 \%$ and $2.5 \%$ of both beneficiaries and non-beneficiaries have household size of 10 and above. The average household size both BOA loan Beneficiaries and Non-Beneficiaries is about 6 persons.

This result shows that family size is very important as source of labour in Artisanal fishing business. This position has earlier been stressed by Adegbite (2008). He upholds that the larger the family size, the more likelihood of sustainable labour, as these family members become part of the labour force.

\subsubsection{Level of Education}

From Table 1.0, it could be seen that all the respondents have formal education. $30 \%$ and $12.5 \%$ of both loan beneficiaries and non-beneficiaries had Primary Education, $66.67 \%$ and $77.5 \%$ of beneficiaries and non-beneficiaries had Secondary Education while 3.3\% and 10\% of beneficiaries and non-beneficiaries have Tertiary Education.

This result shows that all the respondents have one form of formal education or the other, and it is very important to say here that the level of education influences their awareness in modern fishing practice. This is contrary to the findings of Ozor and Okwuche (1998) that most people who engage in fishing and farming activities were drop-outs from school.

\subsubsection{Major Occupation}

Table 1 Showed that the Major Occupation of respondents was fishing. $96.7 \%$ and $87.5 \%$ of both beneficiaries and non-beneficiaries respectively had fishing as major occupation while $3.33 \%$ and $12.5 \%$ of beneficiaries and nonbeneficiaries were civil servants who took fishing as additional source of income for their families. This result confirmed the assertion that people of these riverine communities in Rivers State were predominantly fishermen and artisanal fishing is primarily occupation.

\subsection{Years of Experience in Fishing}

Table 1 Shows that $50 \%$ and $30 \%$ of beneficiaries and non-beneficiaries have between 16-20years experience in fishing. $33.3 \%$ and $12.5 \%$ had 21 years and above, $13.3 \%$ and $50 \%$ beneficiaries and non-beneficiaries had $11-15 \mathrm{yrs}$ experiences $3.3 \%$ and 5.05 have $6-10 y e a s$ experience, while only $2.5 \%$ non-beneficiaries have $1-5$ years of experience in fishing.

A general consideration shows that average years of experience of loan beneficiaries was 18.7years while that of non-beneficiaries was 15.2years. This result indicates that most of these fishermen saw artisanal fishing as a sole means of livelihood and over the years gained experience as full-time fishermen having artisanal fishing as primary occupation.

Most of the respondents have been in fishing business between 11-20years. This again was very important factor, because experience is critical to the success of artisanal fishing in present day harsh environment, which is full of many challenges. This position had earlier been stressed by Kudi et al (2008), Inoni et al. (2007).

\subsection{Membership of Co-operative Society}

Table 1 showed that $83.3 \%$ and $62.5 \%$ of both beneficiaries and non-beneficiaries belong to Co-operative Society, while $16.67 \%$ and 37.5 both beneficiaries and non-beneficiaries respectively do not. This was due to the sensitization and awareness through the umbrella body called 'AFAAN' All Farmers Apex Association of Nigeria. Encouraging farmers and fishermen to belong as well as organize themselves into co-operatives for better co-ordination and recognition by Government and Non-Governmental Agencies. 


\subsection{Religion of Respondents}

Table 1 Shows that $70 \%$ of both beneficiaries as well as non-beneficiaries were Christians, $26.6 \%$ and $20 \%$ respectively of both beneficiaries and non-beneficiaries practice Traditional African religion, while 3.3\% and $10 \%$ of beneficiaries and non-beneficiaries are Muslims. This shows that artisanal fishing cuts across different religion and forms of religion cannot be a barrier, and that fish consumption is not discriminated on the basis of religion.

\subsection{Details of NACRDB Loan to Respondents}

\begin{tabular}{|c|c|c|c|}
\hline \multicolumn{4}{|c|}{ Loan Beneficiaries } \\
\hline & Frequency & $\mathbf{\%}$ & Mean \\
\hline Types of Loan & & & \\
\hline Cash & 60 & 100 & \\
\hline Kind & Nil & 0 & \\
\hline Total & 60 & 100 & \\
\hline Individual & 10 & 16.67 & \\
\hline Co-operative & 50 & 83.33 & \\
\hline Total & 60 & 100 & \\
\hline Amount Approved & & & \\
\hline $50,000-100,000$ & 40 & 66.67 & \\
\hline $100,000-150,000$ & 5 & 8.33 & \\
\hline $150,000-200,000$ & 3 & 5.0 & \\
\hline $200,000-250,000$ & 2 & 3.33 & \\
\hline $500,000-1000,000$ & 10 & 16.67 & \\
\hline $1000,000-1500,000$ & 0 & & \\
\hline $1500,000-2000,000$ & 0 & & \\
\hline 2000,000 -Above & 0 & & \\
\hline Total & 60 & 100 & 201666.67 \\
\hline Rate of Interest (8\%) & & & \\
\hline Above & & & \\
\hline Insurance (Type) & & & \\
\hline NAIC 3.75\% & & & \\
\hline Any other Nil & & & \\
\hline Year Loan was Obtained & & & \\
\hline 2005 & - & - & \\
\hline 2006 & 5 & 8.33 & \\
\hline 2007 & 5 & 8.33 & \\
\hline 2008 & 50 & 83.33 & \\
\hline 2019 & - & - & \\
\hline 2010 & 60 & 100 & \\
\hline Total & - & - & \\
\hline
\end{tabular}

Table 2: Beneficiaries of the Nigerian Agriculture Co-Operative and

Rural Development Bank Loan

Source: Field Survey, 2019

Table 2 is showing a Summary of Loan Beneficiaries of NACRDB

\subsection{Loan Beneficiaries and Forms of Loan}

Table 2 Shows that all the respondents' loan beneficiaries had cash disbursement 100\%. 83.10\% of beneficiaries were in Co-operative Societies while $17 \%$ was directly to individual fishers. This shows that must beneficiaries were members of Co-operative Societies who were certified by all farmers Apex Association of Nigeria 'AFAAN'. S they were properly organised as to obtain the Bank loan.

\subsection{Amount of Loan}

Table 2.0 Shows that $66.67 \%$ of respondents received between $50,000-100,000$ Loan, $8.33 \%$ received 100,000 $150,0005 \%$ had $150,000-200,000$. While $3.33 \%$ had 200,000-250,000, but 16.67\% received between 500,000-100,000. These were Co-operative Societies that received disbursement into their co-operative accounts.

The result implies that greater percentage, about $67 \%$ of the loan beneficiaries received between $50,000-100,000$ only. On the general view the average amount of loan by respondent will be about 201,666.67. This is due to the fact that most of the fishermen could not afford a higher mandatory deposit required by the bank, because the higher the amount the higher the required cash deposit. 


\subsection{Insurance}

As a matter of policy all NACRDB Loans must have National Agricultural Insurance Co-operation (NAIC) Cover at $3.75 \%$ of Loan amount. For the respondent no other form of insurance aside 'NAIC'. The loan itself had an interest rate of $8 \%$ per annum.

\subsection{Year Loan Was Obtained}

Table 2 Shows that, about $83.4 \%$ of the loans were obtained in the year 2008, the rest were in 2006 and 2007, with $8.3,8.3 \%$ respectively. Between 2005-2007, the fishermen actually were reluctant and sceptical about the loan later the awareness improved and a good number applied for the loan in 2008, which gave rise to the volume /Amount of loan disbursed in 2008 as against the previous years.

\begin{tabular}{|c|c|c|c|c|c|c|}
\hline \multirow[b]{2}{*}{ Challenges } & 4 & 3 & 2 & $\mathbf{1}$ & & \\
\hline & $\begin{array}{c}\text { Very } \\
\text { Serious } \\
\text { Problem } \\
\text { VSP }\end{array}$ & $\begin{array}{c}\text { Serious } \\
\text { Problem } \\
\text { SP }\end{array}$ & $\begin{array}{c}\text { Not } \\
\text { Serious } \\
\text { Problem } \\
\text { NSP }\end{array}$ & Undecided & Total & Mean \\
\hline Distance to the Bank & 10 & 46 & 3 & 1 & 185 & 3.08 \\
\hline Attitude of Bank staff & 5 & 10 & 40 & 5 & 135 & 2.25 \\
\hline Mandatory Deposit requirement & 2 & 48 & 10 & - & 154 & 2.56 \\
\hline $\begin{array}{c}\text { Documentation Bureaucratic Bottle } \\
\text { neck }\end{array}$ & 10 & 45 & 4 & 1 & 184 & 3.06 \\
\hline Time and Amount of Loan & 15 & 25 & 15 & 5 & 170 & 2.88 \\
\hline
\end{tabular}

Table 3: Challenges and Difficulties in Obtaining Loan from Nacrdb Ltd (Aka Boa Ltd)

Source: Field Survey, 2019

Table 3 is showing a Summary of Challenges and Difficulties of obtaining Loan from NACRDB Ltd (aka Boa Ltd)

\subsection{Challenges of Obtaining NACRDB Loan}

Table 3shows the result from the responses of the beneficiaries of Bank of Agriculture Loan. The result shows that all the variables except one (Attitude of bank staff) are identified as significant challenges to getting or obtaining loans from Bank of Agriculture. This is because they all have a mean value above 2.5, according to from the 4-point Likert scale ranking, any option that has a mean value of 2.50 and above is seen as a serious challenge. Distance to the bank and Documentation bureaucracy with mean values of 3.08 and 3.06 could be identified as very serious challenge with very high mean value. On the other hand, time and amount of loan, 2.83 , mandatory deposit requirement 2.56 are also a problem to obtaining the bank loan.

However, attitude of bank staff was not identified as a challenge with mean value of 2.25 , this is below 2.50 . This result agrees with the conclusion of other scholars. Malachy (1992) Agrees that distance is a serious factor and encouraged the establishment of Rural Banking.

Ezekiel M. (2018) identified Administrative bottle necks as a serious hurdle in obtaining Bank loan, so also was the view of Olaoye et al. (2012). He also stated that collateral and Minimum requirement poses a great challenge to rural farmers and fishers in obtaining loan from the bank.

\begin{tabular}{|c|c|c|c|c|c|c|}
\hline & Beneficiaries & & & \multicolumn{3}{|c|}{ Non beneficiaries } \\
\hline & Frequency & $\mathbf{\%}$ & Mean & Frequency & \% & Mean \\
\hline $500,000-1000,000$ & 2 & 3.33 & & 15 & 35 & \\
\hline $1000,000-2000,000$ & 6 & 10 & & 23 & 57.5 & \\
\hline $2000,000-3000,000$ & 8 & 13.33 & & 3 & 7.5 & \\
\hline $3000,000-4,000000$ & 29 & 48.34 & & - & - & \\
\hline $4,000,000-5000,000$ & 12 & 20 & & - & - & \\
\hline $5,000,000-$ Above & 3 & 5 & & - & - & \\
\hline & 60 & 100 & $3,375,000$ & 40 & 100 & $1,312,500$ \\
\hline
\end{tabular}

Table 4: Distribution of Annual Income of Loan Beneficiaries and Non-Beneficiaries Source: Field Survey, 2019

\subsection{Distribution of Annual Income}

Table 4Shows that $48.34 \%$ which is the highest percentage of the respondent's earnings respondents earned Annual Income of (3million-4million). The average income for beneficiaries of NACRDB loan was 3,375000. About 3.3\% of the beneficiaries earned between $(500,000-1000,000)$ per annum, whereas the highest income for non-beneficiaries was between $1000-000,-2000,000$ with about $57.7 \%$, only about $7.5 \%$ of non-beneficiaries had annual income of (2million3 million). The average income for non-beneficiaries is (1.3million).

The study showed that lack of access to credit is identified as one of the constraints faced by the non-beneficiaries. This is in line with the findings of Olaoye et al. (2012), Adebayo, (2002), Okwuche et al (1998) who observed that those who had access to credit boasted their revenue and earned more income due to expansion of production activities. 


\subsection{Distribution of Impact of Loan to Fishers}

\begin{tabular}{|c|c|c|c|c|c|c|}
\hline \multirow[b]{2}{*}{ Areas of Impact } & 4 & 3 & 2 & 1 & & \\
\hline & $\begin{array}{c}\text { Very } \\
\text { Great Impact } \\
\text { VGI }\end{array}$ & $\begin{array}{c}\text { Great } \\
\text { Impact } \\
\text { (GI) }\end{array}$ & $\begin{array}{c}\text { Small } \\
\text { Impact } \\
\text { (SI) }\end{array}$ & $\begin{array}{c}\text { No. Impact } \\
\text { (NI) }\end{array}$ & Total & Mean \\
\hline Increase in Revenue & 45 & 12 & 3 & 0 & 222 & 3.70 \\
\hline Improvement in Livelihood & 40 & 10 & 5 & 5 & 205 & 3.42 \\
\hline Expansion of fishing Activities & 47 & 10 & 3 & 0 & 224 & 3.73 \\
\hline Increase in overall output & 45 & 13 & 2 & 0 & 223 & 3.72 \\
\hline Poverty Alleviation & 20 & 30 & 10 & 10 & 200 & 3.22 \\
\hline Generated More Employment & 40 & 10 & 7 & 3 & 207 & 3.45 \\
\hline Reduction of Wastage & 10 & 30 & 20 & 0 & 170 & 2.83 \\
\hline $\begin{array}{l}\text { Enhanced use of better Equipment } \\
\qquad \text { Size }\end{array}$ & 25 & 35 & 0 & 0 & 0 & 3.42 \\
\hline Increase in family size & - & 5 & 15 & 40 & 85 & 1.42 \\
\hline Improved food security & 2 & 38 & 15 & 5 & 157 & 2.62 \\
\hline
\end{tabular}

Table 5: Impact of Nigerian Agric. Co-Operative and Rural Development Bank Loan on Artisanal Fishermen Source: Field Survey, 2019

\subsection{Effect of NACRDB Loan on Artisanal Fishers}

From Table 5, it was confirmed that all the respondents, representing $100 \%$ accepted that their revenue increased due to the loan. While $96.67 \%$ agreed there was increase in overall output, about $100 \%$ agreed there was expansion of their fishing activities which resulted in increase in overall output. about $93 \%$ accepted that the loan enhanced the procurement of better equipment while $91.67 \%$ agreed it improved food security, about $88.33 \%$ said it generated more employment because as they expand their operations, they required additional labour about $83.3 \%$ admitted Improvement in livelihood as their revenue increase, so there was corresponding effect on standard of living, consequently, there was alleviation poverty as admitted by $66.67 \%$. There was also a positive impact on reduction of wastage, 58.33\% agree that as their revenue increased, they were able to acquire equipment for processing and preservation of their catch. Only about $20 \%$ indicated increase in family size.

An over view of the results shows that it agrees or aligns with the position of Adams (1984) who identified bank loan/credit as an effective way of transforming and improving beneficiary's income. Diagne and Zeller (2001) maintained that credit can impact on the welfare of beneficiaries, therefore, he emphasized that access should be given to rural folks. Olaoye et al. (2012) concluded that beneficiaries of Bank of Agriculture loan had increased output, better sales, increased revenue and expansion of their investment. It was due to its relevance that Uzuagu (1981) emphasized the need for improved funding and increased access to bank loan. Olayide (1979), Adeyemo \& Adekun (1985), Osuntogun (1987) are all of the same view.

\begin{tabular}{|c|c|c|c|c|c|c|c|c|c|c|c|c|}
\hline \multirow{2}{*}{$\begin{array}{l}\text { Description/Areas of } \\
\text { Constraints }\end{array}$} & \multicolumn{6}{|c|}{ Beneficiaries } & \multicolumn{6}{|c|}{ Non-Beneficiaries } \\
\hline & 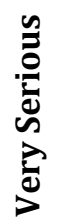 & $\stackrel{\mathscr{a}}{0}$ & 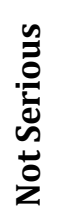 & 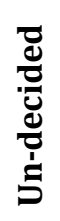 & $\stackrel{\pi}{0}$ & $\sum_{\Sigma}^{\bar{\Xi}}$ & 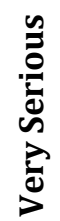 & 竧 & 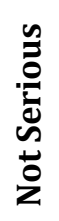 & 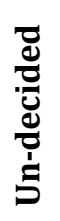 & $\stackrel{\pi}{0}$ & $\sum_{\tilde{\pi}}^{\pi}$ \\
\hline Lack of Equipment/Gears & 40 & 17 & 3 & 0 & 217 & 3.62 & 38 & 2 & 0 & 0 & 158 & 3.95 \\
\hline Insecurity of Water ways & 52 & 8 & 0 & 0 & 232 & 3.87 & 35 & 5 & 0 & 0 & 155 & 3.87 \\
\hline Lack of Capital/Finance & 6 & 50 & 0 & 4 & 178 & 2.97 & 40 & 0 & 0 & 0 & 160 & 4.0 \\
\hline $\begin{array}{c}\text { Wastage due to } \\
\text { Inadequate Storage \& } \\
\text { Processing facilities }\end{array}$ & 0 & 34 & 20 & 6 & 148 & 2.45 & 10 & 20 & 5 & 5 & 115 & 2.87 \\
\hline Insufficient Labour & 0 & 0 & 58 & 2 & 118 & 1.97 & 0 & 0 & 40 & 0 & 80 & 2.0 \\
\hline $\begin{array}{c}\text { Activities of Oil } \\
\text { Exploration Companies }\end{array}$ & 30 & 28 & 2 & 0 & 208 & 3.47 & 20 & 15 & 3 & 2 & 133 & 3.33 \\
\hline Poor/Insufficient Market & 0 & 0 & 58 & 2 & 118 & 1.97 & 0 & 0 & 39 & 1 & 79 & 1.97 \\
\hline High Cost of Fishing Gears & 20 & 38 & 0 & 2 & 196 & 3.27 & 40 & 0 & 0 & 0 & 160 & 4.0 \\
\hline
\end{tabular}

Table 6: The Constraints Militating against Artisanal Fishing in Rivers State

Source: Field Survey, 2019

\subsection{Constraints Militating Against Artisanal Fishing}

Table 6.0 shows the frequency mean distribution of factors or constraints militating against artisanal fishing operations among both beneficiaries and non-beneficiaries of the Bank of Agriculture loan in Rivers State. The decision 
rule is that any frequency mean below 2.5 is considered not to be a major constraint while those with frequency mean of 2.5 and above are major constraints to artisanal fishing in the state. Therefore, lack of equipment and gears with 3.62 and 3.95 respectively for loan beneficiaries and non-beneficiaries was considered a major constraint by both groups. Also, insecurity of water ways had mean 3.87 and 3.87 for both groups. This again was considered a very serious constraint by both.

This result agrees with the position of Chilaka et-al (2014), Tasie and Willicox (2017), who identified high cost of gears, lack of credit, low income, inadequate storage and processing facilities as factors militating against artisanal fishing in Nigeria. Also Caddy J.P (1997), F.A.O (1995) stressed the impact of oil mining activities, pollution of water with industrial waste etc, as very serious threat to artisanal fishing and marine lives.

Effiong and Ogbonna, (2017) also agrees that environmental pollution, Global warming were serious factors, affecting the fishery sector of our economy.

Olalekan et al. (2018) grouped them as human and environmental factors. Pradham et al. (2004) stated that cost is a major factor militating against fishing, this position also agrees with the result of this study.

\section{Conclusion and Recommendation}

\subsection{Conclusion}

This study was carried out to examine the effect or impact of bank credit (Loan) from the bank of Agriculture formally known as Nigeria Agricultural Co-operative and Rural Development Bank (NACRDB) Limited on artisanal fishing in Rivers State. From the result, socio-economic characteristics of the respondents shows that average age of loan beneficiaries was 47.3 years while non-beneficiaries was 42.9 . On gender, about $86.67 \%$ of beneficiaries and $70 \%$ of nonbeneficiaries were males, while 13.33 and 30\% respectively were female, meaning that more males were engaged in artisanal fishing than female. The study also showed that most of the respondents were married with average family size of 5.6 and 5 for both beneficiaries and non-beneficiaries, this is also important because most times, family members provide the labour and helping hands in the business. All the respondents have one form of formal education or the other, with about $66.67 \%$ and $77.5 \%$ of beneficiaries and non-beneficiaries having secondary education. An average 18.67 and 15.25 years of experience was recorded for beneficiaries and non-beneficiaries. 83.33\% of beneficiaries belong to Cooperative society but only $62.5 \%$ of non-beneficiaries belong to co-operative. Based on the findings of this study there is a significant difference between the profit level of beneficiaries of the Agricultural bank loan and non-beneficiaries due to the impact of the loan. The loan helped them to expand the scope of their operation, purchase more equipment to enhance their fishing activities, increase over-all output, increase revenue and enhance income. There were challenges encountered in course of obtaining the loan, such as distance they travel to come to the city where the bank is located, mandatory deposit required by the bank, documentation bureaucracy and timing as well as amount of loan were challenges recorded. The study also identified some constraint militating against artisanal fishing in the state, such includes lack of equipment and gears, insecurity of the water ways due to piracy and activities of militants, also the effects of oil exploration which results in pollution of the water and aquatic environment, lack of capital and high cost of fishing gears are major constraints.

Based on the finding, the follow recommendations were made: Government should re-capitalize the bank as to make more funds available for lending. More attention should be focused on granting Loans to rural, especially artisanal fisher folks and efforts should be made to ensure that real and genuine fishers are identified for the loan. The bank is encouraged to open some rural branches and cash offices nearer to the people.

Government should subsidize the cost of fishing gears and equipment. Sincere and adequate policing of the water ways to check the activities of sea pirates and militants.

\subsection{Recommendations}

That Multi-national oil companies should adopt international best practices to avoid pollution of our waters and contaminate our marine environment. Other agencies of Government and Non-Governmental organizations, should be encouraged to make funds available for establishment of more fishing settlements in the state. There should be a review in the amount of loan and the timing in accordance with present day economic realities.

\section{References}

i. Abdulaziz, N. (2007) Achieving our vision 2020- A paper at a workshop under the National Poverty Eradication Programme (NAPEP). And credit delivery programme (CDP).

ii. Adams, W. \& Dale, T. (1984). 'Effects of Finance on Rural Development' Underling Rural Development with Cheap credit. West Reviews press London pp. 11-12.

iii. Adegbite, D. A \& Oluwalana, E.O (2004). Revolving Loan scheme as a poverty alleviation strategy. A case study of Women Groups in UNAAB Extension villages. FAMAN Journal 7(2).18-32.

iv. Adegbite, D. A \& Oluwalana, E.O (2004). Revolving Loan scheme as a poverty alleviation strategy. A case study of Women Groups in UNAAB Extension villages. FAMAN Journal 7(2).18-32.

v. Adegeye, A.J \& Dittoh, J. S. (1985) Essentials of Agricultural. Economics, impact of publication Nigeria Limited. 164-177.

vi. Adeyemo, K. \& Adekun, S. (1985). 'An Examination of Agricultural Loan Administration of the Agricultural Development Bank in Ghana'. In Nigerian Journal of Financial Management. Enugu. Center for Financial Management and Research Institute of Management and Technology. Vol.2: No.2. 
vii. Bellow, M.O. (2000). Categorization of Potential Adopters for Organic -Based Fertilizers Among Farmers in Oyo. B. Agric. Project Paper. University of Agric. Abeokuta. Pp.89.

viii. Caddy, J.F. (1997). Establishing a Consultative Mechanism for Managing Shared Stocks within the Jurisdiction of Contiguous States. Proceeding of the Joint Workshop on taking stock; Defining and measuring shared Resources: July 15-16-1997, Darwin Australia pp. 81-124.

ix. Diagne, A. and Zeller, M. (2001) Access to credit and its impact on welfare in Malawi; Research Report 116 International food Policy Research Institute Washington, D.C

x. Ezekiel, M. (2018). Guardian Newspaper-23 July 2018. Challenges of Agricultural lending.

xi. Inoni, D. C and Oyaide, W.J. (2007) Socio-economic Analysis of Artisanal Fishing in the South-Agro ecological Zone of Delta State, Nigeria. Agri.Tropica Et Stubtro. 40(4)135-139

xii. Kudi, T. M., Bako, F. P, \& Atala, T.K (2008). Economics of Fish Production in Kaduna State. Nigeria. Journal of Agricultural and Biological Sciences. 3 (5 \& 6):17-21.

xiii. Lahai, B.A.N, Goldey, P.A \& Jones, G.E. (2000). 'The Gender of Extension Agents and Farmers access to and Participation in Agriculture in Nigeria'. Journal of Agricultural Education and Extension. 6(4) 223-233.

xiv. Nwankwo, G.O. (1980). The financial Systems, Macmillan London. Pp 2-9.

xv. Okwuche, V.A, Voh, J.P. \& Ogunwale, S.A. (1998) Socio-Economic Characteristics influencing Adoption Behavior of Women Co-operative and Non-Co-operators in Oju LGA of Benue State: Journal of Agricultural Extension. 2:31-38. Terry. A. Olowu (ed.).

xvi. Olalekan, J. O. \& Wahab, G. O. (2018). Marine Fisheries in Nigeria. A Review, Marine Ecology-Biotio and Abiotic Interactions, from

xvii. Olaoye, O.J.O, A.B. Adelaja, S.S. Ashley- Dejo, G.A.K. Omoyinmi, A.A. Idowu \& C.B. Odebiyi (2012). Impact of Nigerian Agric, Co-operative and Rural Development Bank (NACRDB) loan on fish farming enterprises in Ogun State, Nigeria. Nigerian Journal of Fisheries. 9(1)

xviii. Olayide, S.O. (1979). 'Food Production in Nigeria' Report of Agricultural Statistics. Taskforce. Ibadan Nigeria.

xix. Olomola, A.S. (1988). 'Agricultural Finance'. In A. O. Phillips \& S. Tunji, Titilola (eds.) Nigeria in 2010 NISER. Ibadan Nigeria. Pp 51-62.

xx. Pradhan, N. \& Leung, P. (2004) Modelling Entry, Stay and Exit Decisions of the Long line Fishers in Hawaii; Marine Policy. 28:311-324

xxi. Shonfied, A. (1960). Attack on World Poverty. New York Random House. USA.

xxii. Uzuagu, W.O. (1981). Money and Banking in Nigeria, Enugu. Fourth Dimension Publishers. 